\title{
O SÍMBOLO ESVAZIADO: A TEORIA DO ROMANCE DO JOVEM GYÖRGY LUKÁCS
}

\author{
Arlenice Almeida da Silva ${ }^{1}$
}

- RESUMO: O presente artigo investiga como A teoria do romance (1916) de G. Lukács, um texto fragmentado e de ocasião, tornou-se um clássico da reflexão sobre a modernidade. Para Lukács, o romance é a forma artística que corresponde à fratura entre o sujeito e o mundo, vivida pelo homem contemporâneo. Utilizando o conceito de "símbolo esvaziado" este texto apreende em que medida o autor ao rever as classificações anteriores sobre o gênero romance, perpetua a tradição romântica ou rompe com ela, elaborando conceitos originais para a compreensão da modernidade na literatura.

- PALAVRAS-CHAVE: Lukács, romance, modernidade, romantismo, simbolização.

A vida de um homem verdadeiramente exemplar deve ser integralmente simbólica.

Friedrich Novalis

Por que um texto torna-se clássico? Por que continua sendo lido pelas gerações seguintes? A perenidade de um ensaio soturno como A teoria do romance de G. Lukács, publicado pela primeira vez em 1916, e o esquecimento de suas outras obras mais solares, desconcerta. Melancolia, desintegração, dissolução, incompatibilidade, abismo entre pensamento e vida, fratura entre as exigências da inteligência e as da ação: eis os termos utilizados para nomear a inexorável modernidade que a forma romance sintetiza.

Qual seria o poder de atração do texto? A contundência de seu conteúdo ou as imprecisões e arestas formais? Sabemos que ele foi pensado como

1 Arlenice Almeida da Silva é Professora Assistente-Doutora no Departamento de Filosofia da FFCUnesp, campus de Marília. 
uma introdução a uma reflexão sobre a obra de Dostoiévski, mas que, na verdade, foi publicado isolado e antecipadamente, em função da percepção de que tinha seu autor de que ele repercutia elementos de sua época, possibilitando tornar-se, assim, uma expressão de "desespero" diante da assombrosa Europa da Primeira Guerra Mundial. Pelas declarações posteriores do próprio autor, sabemos, ainda, que o diagnóstico inexorável e radical anunciava ao mesmo tempo o estado terminal em que a Europa vivia e uma crise cultural que ultrapassava o momento histórico da Guerra, em direção a um questionamento mais amplo e, de resto, apocalíptico - "Quem nos salva da civilização ocidental?" perguntava o jovem Lukács.

A interrogação perturbadora prenunciava a tragédia inerente à vitória da civilização na própria escrita, na forma do ensaio, em uma exposição que não dissolve as tensões, a confusão dos limites e territórios, muito menos esconde a angústia do autor diante de sua desesperada busca pelo sentido em um mundo convencional e opaco. Mesmo que ao final A teoria do romance desemboque em um pequeno vislumbre de esperança, predomina uma narrativa que se demora mais na caracterização dos tempos opacos do que nos harmoniosos, resultando daí uma estrutura teórica de recorte temporal marcada por elipses e imprecisões: não sabemos quando, nem exatamente porquê perdemos a harmonia, isto é, a imanência do sentido à vida. Parece não importar saber em que momento a soleira foi atravessada. Basta reconhecer, apenas, que não estamos em casa, que nossa condição é a de desterro e que nos encontramos sem deus, mas ainda sob a sina de uma "época da perfeita pecaminosidade".

A ausência de balizas históricas concretas atordoa o leitor e reforça a dimensão metafísica do texto: de um lado, encontramos um jovem Lukács idealista, neo-romântico, anticapitalista, que fala em valores, essência, substância, conceitos universais, e, de outro, paralelamente, um autor que busca considerar o legado hegeliano, pensar as categorias estéticas em um plano histórico e não apenas normativo, ao estudar "a dialética históricofilosófica das formas de arte". ${ }^{2}$ Talvez, por essa razão A teoria do romance precise ser inscrita entre a tradição tratadística, que caracterizava a reflexão sobre a arte até meados do século XVIII e que, como os antigos, buscava pensar o efeito da arte em um determinado público, e a estética dita romântica centrada na especulação sobre a autonomia da arte e, em parti-

2 O legado hegeliano n'A teoria do romance é um assunto polêmico. Peter Szondi observa que a antinomia entre sistema e história, presente na obra de Hegel, atua como um tipo de explosivo que provocará o desmoronamento da estética hegeliana e preparará, sobre suas ruínas, o fundamento de uma estética histórica, sem intenção sistemática, no Jovem Lukács e em Walter Benjamin (Szondi, 1974, p.273). 
cular, na especificidade histórica do gênero romance. As dificuldades do texto decorrem, em parte, desses afastamentos e aproximações que o texto estabelece seja com o referencial antigo, seja com o idealismo alemão e, particularmente, com o que chamamos, grosso modo, de Romantismo. A intuição desse texto é a de que o debate sobre tais problemas conceituais lance uma luz sobre o apelo "clássico", quase um século depois, de A teoria do romance.

Se começarmos pelo fim, sabemos qual a direção da trajetória posterior do autor: a de historicizar radicalmente as formas literárias e condenar o caráter abstrato e idealista dos resultados de A teoria do romance; para tanto basta ler o contundente prefácio de 1962. ${ }^{3}$ Trajetória que, se observada com lentes históricas, revela uma rota de fuga do niilismo e do desencantamento que A teoria do romance expressava e a literatura moderna de vanguarda, segundo Lukács, cada vez mais encerrava o leitor. Sua tentativa, a partir dos anos 1920, era a de ver no romance realista clássico - Scott, Balzac, Tolstoi, - a herança da capacidade narrativa que, ao configurar as experiências vividas, teria possibilitado ao gênero épico conferir novamente algum sentido à vida.

Contudo, para um ensaio que tem como marca de sua fortuna crítica ter sido lido de forma autônoma, talvez seja ainda mais urgente retardar um pouco o desfecho da trajetória do autor, para que o texto possa ainda ser compreendido também retrospectivamente. ${ }^{4}$ Portando, qual a singularidade deste texto de juventude? Qual a distância que o autor estabelece com o romantismo? Inicialmente, seria interessante perguntar por que Lukács perpetua e retoma em 1914-15 balizas produzidas pela "Goethezeit", ou seja, qual a distância que A teoria do romance estabelece com esta tradição? ${ }^{5}$

3 Sabe-se, por outro lado, que A teoria do romance foi concebida como uma introdução e uma apresentação histórico-filosófica da obra poética de Dostoiévsky que, para M. Löwy, "ultrapassaria o terreno puramente estético e literário em direção a uma problemática ético-política" (cf. Löwy, 1979, pp.123-9). Sugestão que foi levada a bom termo por Carlos Eduardo Jordão Machado, em As formas e a vida, ao tomar as "Anotações sobre Dostoiévski" como a "verdade" d'A teoria do romance. Para ele, "apesar de Lukács colocar-se como tarefa mostrar de que modo o romance se constitui enquanto forma literária da modernidade par excellence, As Anotações e esboços sobre Dostoiévski estão em conexão direta com a interpretação das relações contrapostas entre forma e vida dos ensaios de A Alma e as formas. Estes últimos oferecem uma "metafísica da tragédia" e as Anotações, uma "metafísica da épica" (Machado, 2004, p.61).

4 Vale destacar e relembrar que Fredric Jameson propôs, com brilho e originalidade, o caminho inverso, ou seja, compreender os primeiros trabalhos de Lukács à luz dos últimos (cf. Jameson, 1985, p.129).

5 Rochlitz demonstra que desde 1907, a partir de seu ensaio sobre Novalis, Lukács já procurava realizar uma crítica ao romantismo, mas ainda no plano de uma filosofia da arte. Neste sentido, A teoria do romance seria uma continuação ampliada deste projeto, agora na direção de uma análise histórico-filosófica (cf. Rochlitz, 1981, p.10). 
A cisão que o ensaio revela não é original, pois já era clássica a contraposição entre os antigos e os modernos; entre uma experiência da antiguidade vivida e apresentada como uma unidade perfeita e o mundo moderno vivido como cindido. Ora, tal contraposição já estava presente no primeiro romantismo em Winckelmann ${ }^{6}$ e em sua reflexão sobre a arte grega e, em F. Schlegel, só para mencionarmos dois representantes da mesma tendência. Se Winckelmann apenas constata a cisão, F. Schlegel, talvez uma das influências mais decisivas no jovem Lukács, contrapõe em uma filosofia da história a experiência da antiguidade à da época moderna. Enquanto a primeira teria sido marcada por uma formação natural (naturliche Bildung), dotada de coesão e unidade, a segunda assinalaria uma formação artificial (kunstliche Bildung), na qual imperaria a fragmentação, a força do particular e de uma "individualidade original e interessante", ou seja, positivamente, um espaço no qual se daria a emancipação do entendimento (cf.Szondi, 1974, p.96).

Em Lukács, a cisão é da mesma raiz, e o problema que é colocado para a arte é semelhante: consiste em acatar a cisão e encontrar uma expressão adequada para expressá-la. Mas, aqui, não se trata de tomar como modelo ou imitar a "perfeição" dos antigos, como em Winckelmann, nem de superar a fratura, afastando-se da antiguidade e anunciando a dissolução dos gêneros e o surgimento de um gênero único na poesia romântica, como em Schlegel, mas de marcar a cisão, afirmar sua presença, ousando, assim, permanecer no "meramente existente"; denunciando, enfim, a impossibilidade de fazer ressurgir a epopéia antiga na moderna civilização. Se não é mais possível qualquer renovação ou imitação criativa, resta pensar o romance, o épico moderno, em sua especificidade histórica, penetrando na experiência conflitante do dilaceramento, suspendendo a reconciliação, suportando a cisão ao máximo, a ponto de torná-la símbolo da modernidade.

O fim da antiguidade é constatado pela morte da épica antiga, reforçado e marcado pela cisão entre a subjetividade e o sentido, que se traduz na necessidade de uma nova forma, o romance. Trata-se, agora, de marcar essa distância, essa nova situação transcendental, ou seja, perceber que se trata da transição de uma transcendência divina para outra secular, chamada por Lukács de "demoníaca", isto é, de entender o romance como "expressão simbólica" da impossibilidade da harmonia no mundo.

Neste sentido, o conceito que ajuda a pensar essa novidade é o de símbolo, não por acaso a marca central da estética romântica. Como o jo-

6 Winckelmann teria delineado pela primeira vez o problema ao constatar a diferença entre os antigos e modernos, ao falar que os antigos seriam 'unidos' e harmoniosos e sua arte dotada de 'nobre simplicidade e grandeza serena', e os modernos 'cindidos', referindo-se à separação entre alma e corpo, sujeito e mundo em Geschichte der Kunst des Altertums, publicado em 1764. 
vem Lukács, ao refletir sobre o romance, pensa o problema da significação em arte? ${ }^{7}$ Ela é um signo arbitrário que designa por convenção, como nos antigos e como ainda em Moritz; ou a "unidade de ser e significação", na qual o signo artístico é entendido como instante místico, em que se dá uma experiência simbólica que remete a algo exterior a obra de arte? O símbolo é pensado, nos termos de Kant, como o que é "próprio à maneira intuitiva e sensitiva de apreensão das coisas" (Kant, 1993, pp.195-9)? Ou ainda, como podemos situar A teoria do romance diante do paradoxo provocativo de Adorno: "a representação ou é realista ou é simbólica" (Adorno, 1998, p.240)?

Em primeiro lugar, o centro da cisão é o conceito de totalidade, presente também em boa parte da estética romântica. Mas enquanto, em linhas gerais, os românticos falavam em totalidade na obra, em "intuição do todo indistinto" (Novalis,1988, p.131); deslocamento em direção ao indeterminado, ao inesgotável, ao futuro, pela e na obra, Lukács fala em totalidade do ser. Assim, seguindo a tradição metafísica minada pela crise kantiana, Lukács pensa o ser, sua existência no mundo e, principalmente, como Fichte, sustenta o primado da razão prática. O que lhe permite reconhecer uma cisão que se dá na relação de representação entre a obra e o mundo, e não na relação de expressão entre a obra e o artista (cf. Todorov, 1977, p.186). Tal manobra problemática permite-lhe acatar o rompimento com o referencial antigo, mas continuar rendendo-lhe homenagens póstumas. A obra, no caso, a epopéia antiga que continua lhe servindo de modelo comparativo, configurava o mundo entendido como totalidade auto-suficiente; na Grécia o acontecimento era figurado ao adquirir peso e importância para a comunidade, índice de vinculação de um destino com a totalidade. A forma épica correspondia, assim, a uma estrutura temporal: a epopéia antiga assinalava uma integração entre o "eu e o mundo, ser e destino, aventura e perfeição, vida e essência". O sentido era conhecido, "palpável e abarcável com a vista" e o espírito apenas acolhia ou identificava tal sentido. De tal forma que era o princípio da imitação o elemento formal que definia essas culturas fechadas e homogêneas: "criar", diz Lukács, significava "apenas copiar essencialidades visíveis e eternas" (Lukács, 2000, p.29). Não havia separação entre estética e ética, entre o belo e o útil, nos termos de Lukács, pois "toda a ação é somente um traje bem-talhado da alma" (idem, p.26).

7 Posteriormente, na produção estética a partir dos anos de 1930, Lukács se tornará um crítico da simbolização, em nome do realismo.O símbolo será visto como um "sucedâneo infeliz para a íntima poesia humana, uma tentativa de suprir com meios artificiais a pobreza interior dos homens e dos acontecimentos",ou ainda "a ilusão de que as coisas podem ter um significado autônomo", que é a seu ver a fonte do simbólico (Lukács, 1960, pp.74-98; também cf. Jameson, 1971, pp.197-9). 
Na modernidade, diferentemente, não é mais possível um acordo perfeito entre o indivíduo e o mundo, uma vez que o primeiro tornou-se problemático e o segundo, contingente; "não há mais totalidade espontânea do ser"; ela é oculta, fugidia. E a forma romance anuncia justamente essa situação de completo desterro. Contudo, os homens não cessam de almejar a totalidade perdida. Se antes a totalidade era espontânea, imediata, agora ela é artificial, produtora: ao mesmo tempo desejo, ausência e signo de um desmoronamento.

A arte, a realidade visionária do mundo que nos é adequado, tornou-se assim independente: ela não é mais uma cópia, pois todos os modelos desapareceram; é uma totalidade criada, pois a unidade natural das esferas metafísicas foi rompida para sempre. (Lukács, 2000, p.34)

Ora, se a Grécia é o passado morto, se não é possível nenhuma ressurreição do helenismo, se o mundo não é mais homogêneo, se a condição moderna é a da fragmentação, como falar em unidade do ser com o mundo, em uma transcendência tornada real? Como o romance pode articular uma vida tornando-a essencial ou estabelecer os liames entre transcendência e imanência, entre ser e mundo? Não seria um procedimento fadado ao fracasso?

A solução encontrada por Lukács é original, pois por meio de um procedimento que chamaremos de uma simbolização esvaziada, ele dialoga ainda com o referencial antigo e, ao mesmo tempo, afasta-se das soluções românticas dadas ao problema da relação entre natureza e história. Ou seja, para Lukács o romance não é uma apoteose formal, síntese de todos os gêneros, como em F. Schlegel, mas ele tem uma especificidade, uma configuração própria na caracterização do tempo que precisa ser desvendada. Os românticos, como F. Schlegel, caracterizavam o presente como um tempo intermediário, ${ }^{8}$ uma etapa provisória, - "um tempo que não é mais, e que ainda não é" -, mas que será no futuro um outro, no qual por meio da ampliação que a obra de arte incitaria - a poesia do infinito (Novalis) - a cisão poderia ser ultrapassada. No famoso fragmento 116, Schlegel afirma:

Somente a poesia [romântica] pode se tornar, como a epopéia, um espelho do inteiro mundo circundante, um retrato da época. E, contudo pode também, no mais das vezes, pairar suspensa nas asas da reflexão poética, eqüidistante do que é exposto e daquele que expõe, livre de qualquer interesse real ou ideal, e potenciar continuamente essa reflexão, multiplicá-la como em uma infinita série de espelhos. (Schlegel,1994, p.99)

8 Peter Szondi observa que em Schlegel temos um dos "traços essenciais da filosofia moderna da história: a concepção do tempo como sendo um tempo intermediário, um 'não mais' e um 'ainda não', cuja negatividade não adquire sentido a não ser que se advirta que a tese é passado, e que o pressentimento de uma síntese é utopia" (cf. Szondi, 1974, p.96). 
Para Lukács o tempo presente é constitutivo e não um tempo intermediário. Como vimos, A teoria do romance demora-se no presente, naquilo que é, denunciando a ingenuidade e melancolia dessa subjetividade tornada seu próprio objeto, que tem de refletir por não poder agir, dessa "alma vergada sob os ideais". Todo o arcabouço argumentativo da obra visa a acentuar o recorte temporal:

A vida própria da interioridade só é possível e necessária, então, quando a disparidade entre os homens tornou-se um abismo intransponível; quando os deuses se calam e nem o sacrifício nem o êxtase são capazes de puxar pela língua de seus mistérios; quando o mundo das ações desprende-se dos homens e, por essa independência, torna-se oco e incapaz de assimilar em si o verdadeiro sentido das ações, incapaz de tornar-se um símbolo através delas e dissolvê-las em símbolos; quando a interioridade e a aventura estão para sempre divorciadas uma da outra. (Lukács, 2000, pp.66-7)

Mesmo não sendo demarcada cronologicamente, a cisão é apresentada como um resultado histórico: "o romance é a epopéia de uma era para a qual a totalidade extensiva da vida não é mais dada de modo evidente, para a qual a imanência do sentido à vida tornou-se problemática, mas que ainda assim tem por intenção a totalidade." (idem p.55)

Portanto, no romance, a oposição entre realidade e ideal se traduz em uma tensão entre o desejo e a impossibilidade de realização, expresso no anseio configurador do indivíduo problemático; "reside no fato de querer realizar, de algum modo, o âmago de sua interioridade no mundo" (idem, p.142). O desejo aqui é o de ação, o de realização da liberdade no mundo e não apenas na obra de arte ou no pensamento. De tal forma que não é mais possível uma saída plenamente "romântica", nos termos freudianos, sublimada, filiada aos que atribuíam à poesia uma capacidade unificadora e simbólica de alcançar uma harmonia superior, e, assim, pela obra, tornar-se ato. Ou seja, para Lukács não é mais tempo da "arte de viver romântica" e de sua poesia na qual é possível atribuir à cada coisa seu lugar adequado, e assim, criando pela imaginação - 'o caminho da interiorização' - um outro mundo e "para a poesia, tudo torna-se símbolo" (Lukács, 1974, p.86).

Pois, se de um lado, a aspiração pela forma decorre de um "sofrimento metafísico do sujeito" (idem, p.37) ou de uma aspiração essencial da alma (idem, p.88), de outro lado, o discurso sobre a arte está imerso em referenciais externos, atado a um objetivo que lhe é exterior, a existência finita no mundo. Para Lukács, jovem ou velho, só no mundo a alma pode se realizar. De tal forma que é no conceito de intenção de totalidade, ou na aspiração em direção a uma transcendência, que a oposição de Lukács ao movimento romântico, começa a ganhar contornos mais nítidos. Não se trata mais de subestimar a potência da subjetividade que, isolada e na relação com a obra, busca salvar sua alma. Ao contrário, afirmando as aporias de uma saí- 
da transcendental, Lukács insiste em dizer o mundo. Não se trata, ainda, de valorizar a "bela natureza", porque o mundo tornou-se opaco, e não é mais dado de modo claro, direto, imediato, evidente. Ele não pode ser corrigido em função de um "ideal superior". Não, o ponto de partida de Lukács é o da relação cindida entre a interioridade e a exterioridade, isto é, o do desencantamento do mundo; a forma romance assinala o pressuposto de que a cisão é concreta e incontornável. Não é possível sonhar novas unidades nem hipostasiar em existência concreta nossas ilusões: "As fontes cujas águas dissociaram a antiga unidade estão decerto esgotadas, mas os leitos irremediavelmente secos sulcaram para sempre a face do mundo" (idem, p.35). Dada a clareza do enunciado, poderíamos localizar aqui a linha de continuidade na trajetória de Lukács, em outros termos, uma primeira versão de sua posterior teoria do realismo.

A harmonia da antiguidade era, para Lukács, a percepção de que a essência estava presente no seio do mundo social, de uma comunidade. De tal forma que a ação realizava a essência, ou seja, forma e existência se complementavam. A modernidade, ao colocar sob suspeita tal completude, tal "idade de ouro", interroga-a como representação utópica: pois na medida em que forma e mundo são percebidos como separados, é a forma que, agora, tensionada, opera no campo da simbolização, não mais a ação exemplar. Ao denunciar essa fratura e a dissonância que a acompanha, o romance desloca o campo de tensão, passando a operar em um plano simbólico esvaziado, mas que continua objetivando a uma totalidade que fará dele "a forma épica necessária de nossos dias".

Assim, se de um lado a arte é uma esfera entre muitas, ela só se justifi$\mathrm{ca}$, alimentando e dando voz ao desejo de pertencimento se incorporar a fragmentação do mundo, sua insuficiência, e não procurar aniquilar o que lhe é exterior, nem ignorar o mundo. Nos termos lukácsianos, o romance é a possibilidade de "aflorar em símbolo do essencial que há para dizer" (idem, p.90). A forma romance torna-se, então, em função de sua impotência em relação à ação, um mero vislumbre de sentido, constituindo uma nova forma de simbolização. Agora, o sentido da vida se dá no auto-conhecimento, na configuração dada no romance que é irremediavelmente biográfico; "o romance é a forma da virilidade madura" (ibidem), a percepção de que o sentido jamais é capaz de penetrar inteiramente a realidade, o hiato entre interioridade e aventura, ou seja, "o romance é a forma da aventura do valor próprio da interioridade" (idem, p.91); docta ignorantia em relação ao sentido, isto é, a ironia do escritor, "nesse não-querer-saber e nesse não-podersaber" (idem, p.93).

Lukács ao falar em símbolo se insere, desse modo, no debate entre as doutrinas clássicas e a estética moderna, procurando contornar e não aban- 
donar o princípio da imitação, ou seja, nos termos modernos, o princípio da representação na definição do romance.

Mas, o que de essencial pode ser dito pela arte na modernidade? Não seria pouco e redundante a mera afirmação de que não há mais sentido? Afirmar-se-ia, com isso, a autonomia da obra de arte na forma romance e de sua superioridade em relação à natureza? Qual é o estatuto da forma? O que ela configura? Ela continua sendo pensada como instrumento de reconciliação entre alma e essência?

Aqui, novamente o diálogo com os românticos volta a ser produtivo. Procurando atribuir ao belo uma existência autônoma e uma dimensão simbólica e, assim, estruturar uma estética romântica, A. W. Schlegel afirmou, em 1801: "O belo é uma representação simbólica do infinito; pois assim torna-se ao mesmo tempo claro como o infinito pode aparecer no finito" (cf. Todorov, 1977, p.235). Goethe, um dos primeiros autores a definir o simbólico por oposição ao alegórico, afirma que o símbolo é intransitivo e indireto, enquanto que a alegoria transitiva e significa diretamente. Símbolo é a representação operando no particular para significar o universal. A alegoria seria o procedimento de procurar o particular a partir do universal. No geral, o símbolo ganha preferência entre os românticos pela sua característica espontânea, inconsciente, pela capacidade de sintetizar e exprimir o infinito, isto é, o indizível.

A presença da matriz da doutrina romântica em A teoria do romance é nítida, mas outros nomes do repertório romântico podem ser mencionados. E o caso de Friedrich Creuzer e seu Symbolik und Mythologie der alten Volker, besonders der Griechen, de 1810-1812. A contribuição original de Creuzer consistiu em construir um vasto sistema comparativo entre as religiões, fundamentado na semelhança entre os símbolos religiosos, demonstrando sua origem comum e oriental (cf. Munch, 1976, pp.130-1). Ao sustentar que o símbolo é, portanto, uma linguagem de síntese, Creuzer elabora uma singular articulação da oposição entre símbolo e alegoria. ${ }^{9}$ Eis seus termos:

A distinção entre as duas formas [símbolo e alegoria] deve ser procurada no caráter momentâneo, que não existe na alegoria. Uma idéia se abre no símbolo em um momento, inteiramente, atingindo todas as forças de nossa alma. É como um raio que, do fundo obscuro do ser e do pensar, incide diretamente em nosso olho, atravessando toda nossa natureza. A alegoria nos conduz a respeitar e seguir o caminho que toma o pensamento escondido na imagem. Ali [no símbolo] existe uma totalidade momentânea; aqui, existe uma progressão em uma série de momentos. Daí por-

9 Todorov acentua que a contribuição original de Creuzer foi a de unir ao par símbolo-alegoria a categoria do tempo. Symbolik, sua obra principal, é uma ordenação dos símbolos e uma explicação da história primitiva da humanidade, da revelação original ao politeísmo grego. O que será fundamental para a estética do século XX, particularmente em Walter Benjamin (cf. Todorov, 1977, pp.253-9). 
que a alegoria, mas não o símbolo, compreende em si o mito, cuja essência se exprime mais perfeitamente na progressão do poema épico. $(\text { Creuzer,1810,70-71) })^{10}$

Se o que Lukács busca é uma forma de transcendência possibilitada pela e na significação simbólica, o que predomina em A teoria do romance na atribuição do significado pelo romance é uma figura híbrida de símbolo: seja na epopéia antiga, que ao configurar uma totalidade fechada terrena da transcendência que se tornou manifesta, almeja uma compreensão intuitiva, uma relação natural e espontânea, buscando uma fusão entre sujeito e objeto, um vínculo orgânico do indivíduo com a comunidade, seja no romance moderno denunciando a ausência deste mesmo vínculo, mas que ainda almeja a imanência do sentido à vida, o que temos é a traduzibilidade do particular e universal na representação simbólica. Mas, em outros momentos, o enquadramento é difícil, pois, mesmo apontando para a atividade simbólica, a forma romance analisada por Lukács não é breve, clara ou simples, nem sintética, mas marcada por uma estrutura que incorpora não só a fratura entre o eu e o mundo, mas especialmente a temporalidade, além de ser uma forma precária, incompleta, inacabada que se aproximaria, portanto, da alegoria, afastando-se do absoluto, do divino e concentrado-se no sensível, no finito, pelo menos nos termos propostos por Creuzer.

Ora, se a composição do romance é uma "fusão paradoxal de componentes heterogêneos e descontínuos numa organicidade constantemente revogada" (Lukács, 2000,p.85), não estamos diante da mesma noção de símbolo, tal como pensada pelos românticos, mas de um procedimento que refaz o conceito pela adição de elementos históricos. Em A alma e as formas, Lukács já havia assinalado o equívoco da arte romântica de viver: "eles procuraram criar um mundo homogêneo, unitário e orgânico (...) mas perderam a enorme tensão entre a poesia e a vida, que confere a uma e a outra as forças reais e criadoras dos valores" (Lukács,1974, p. 87).

Essa tensão é o mundo cindido apresentado n'A teoria do romance. ${ }^{11} \mathrm{O}$ romance é uma construção "problemática", emblema de uma modernidade

10 Na Origem do drama barroco alemão, - obra contemporânea de A teoria do romance - Walter Benjamin salienta a importância da categoria do tempo nas reflexões românticas de Creuzer, o que lhe possibilita pensar a temporalidade ligada à morte e à figura da alegoria como a "facies hippocratica da história como protopaisagem petrificada. A história em tudo o que nela, desde o início, é prematuro, sofrido e malogrado, se exprime num rosto - não, numa caveira." (...) "Nisso consiste o cerne da visão alegórica: a exposição barroca, mundana, da história como história mundial do sofrimento, significativa apenas nos episódios do declínio. Quanto maior a significação, tanto maior a sujeição à morte (...). Mas se a natureza desde sempre esteve sujeita à morte, desde sempre ela foi alegórica" (Benjamin, 1984, p.188).

11 Para Fredric Jameson toda a obra de Lukács e não apenas A teoria do romance defende a seguinte concepção de símbolo: "a presença do pensamento simbólico ou simbolizante na obra permanece sempre uma indicação de que o significado imediato dos objetos desapareceu: antes de mais nada, 
que perdeu o sentido da vida, mas que faz dessa ausência o pressuposto de uma reflexão sobre a temporalidade. Só na experiência da dissolução e da cisão, o tempo torna-se constitutivo. O romance assimila o tempo real, a duração real, a durée de Bérgson:

somente no romance, diz Lukács, cuja matéria constitui a necessidade da busca e a incapacidade de encontrar a essência, o tempo está implicado na forma: o tempo é a resistência da organicidade presa meramente à vida contra o sentido presente, a vontade de vida em permanecer na própria imanência perfeitamente fechada. (Lukács. 2000, p.129)

A forma do romance é, pois, desejo, reflexão e busca, mas ao mesmo tempo, a forma é também coerção, configuração de "experiências temporais" que "despertam ações e nas ações tem suas origens". Mas, cindido, o indivíduo moderno problemático está condenado à errância no mundo, colocando em suspeição todos os sentidos e valores da Lebenskunst, de toda arte de viver. Ao final do percurso possibilitado pelo romance ele reencontra apenas a si mesmo, sua finitude, suas dúvidas e aspirações. Mas é por essa razão que o romance é também, positivamente, expressão de uma cultura aberta, com um círculo maior, pois o "círculo mágico" da antiguidade, nos termos humboldianos, foi rompido; neste novo círculo, superamos a ingenuidade ao descobrir a produtividade do espírito; inventamos a configuração (a criação de formas); "descobrimos em nós a única substância verdadeira", mas uma "substancialidade que se dissipa em reflexão" (idem, p.31), não se converte em ação.

Do romance brota, portanto, uma dissonância. De um lado, ele permite a constatação da nulidade da ação humana, mas, de outro, há um vislumbre de positividade, pois, enquanto "canto de consolo", que propicia "a recordação e a esperança", é a única configuração que possibilita uma reconciliação, problemática é verdade, entre atividade e contemplação, ou seja, entre o indivíduo e o mundo. E nesse aspecto, ele é uma forma possível, mais do que isso, necessária: é a "situação transcendental da nossa época".

Na segunda parte do ensaio, Lukács estabelece uma tipologia entre as formas romanescas, apontando de um lado, na estrutura formal do idealismo abstrato, um estreitamento da alma em relação ao mundo e, de outro, no romance de desilusão, um estreitamento do mundo em relação à alma. Entre a possibilidade de extraviar-se e a adesão incondicional ao mundo, o resultado é um herói que se afirma por meio de uma solidão resignada. É no

o processo não viria à tona se os objetos não tivessem já se tornado problemáticos em sua natureza" (Jameson, 1985, p.133). 
romance de formação, síntese entre o idealismo abstrato, e o romance de desilusão, que a forma adquire sua melhor possibilidade. O romance de formação pode possibilitar aquilo que Lukács chama de "experiência compreensiva", ou "reflexão polêmica", isto é, "uma experiência que se esforça por ser justa com ambos os lados e vislumbra, na incapacidade da alma em atuar sobre o mundo, não só a falta de essência deste, mas também a fraqueza intrínseca daquela" (idem, p.143). Mas, adverte Lukács, a irrepresentabilidade continua posta, pois não se trata de uma totalidade espontânea do ser, mas de uma configuração consciente; de uma "vontade de formação", expressão ou exemplo de resignação.

Criticando a partir do interior e denunciando os limites do romantismo, Lukács mostra o perigo de um deslizamento solipsista no romance de formação: "o de uma subjetividade não paradigmática, não convertida em símbolo, que tem de romper a forma épica". Ou seja, o perigo do "meramente pessoal, do memorialístico, do caráter fatal, insignificante e mesquinho do meramente privado." (idem, p.144)

Por essa razão, a figura de maior destaque, em Lukács é a da ironia, novamente uma figura romântica: o ponto de vista que ao mesmo tempo não se satisfaz com o mundo, mas dele não se afasta. Ela, a ironia, é o principal elemento do herói problemático que se manifesta em seu caráter demoníaco. Ora, num mundo sem Deus, o demoníaco é o seu substituto: a tendência da alma de separar-se completamente de tudo que não seja a essência; de persegui-la insistentemente, mesmo que para constatar mais uma vez sua impossibilidade. É, por essa razão, que na tipologia que faz da forma romanesca, Lukács atribui ao Dom Quixote de Cervantes, a grande realização do romance na forma do idealismo abstrato, o mérito de ter sido a "primeira grande batalha da interioridade contra a infâmia prosaica da vida exterior". A ironia, como auto-superação da subjetividade que foi aos limites, é a mais alta liberdade possível num mundo sem Deus" (idem, p.96).

Mas se para Friedrich Schlegel a ironia é o elo que apreende a realidade como provisória, tornando relativo e suportável o presente cindido em relação a um futuro unificado na poesia, para Lukács a negatividade da situação só pode ser ultrapassada pela ação. Lukács que, ao final, vê na obra de Dostoiévski uma pequena abertura para a saída do abismo e do mundo cindido, ${ }^{12}$ sabe que "uma totalidade de homens e acontecimentos só é possível

12 Michel Löwy, discordando de Lucien Goldmann, sustenta que A teoria do romance foi uma obra marcada por uma genial intuição: "A teoria do romance constitui para Lukács o primeiro passo além da Weltanschauung trágica em direção à dialética histórica. Encontra-se aí a esperança e mesmo o pressentimento da mudança do mundo, apenas dois anos antes da Revolução Russa. (...) Mas a esperança se situa para além do romance e da época que ele exprime, numa nova epopéia da qual a literatura russa é o primeiro esboço, e no mundo novo que esta anuncia" (Löwy, 1990, p.126). 
sobre o solo da cultura, qualquer que seja a atitude que se adote em relação a ela" (idem, p.154). Mas a cultura é, ainda, negativamente, o mundo circundante, "o mundo das convenções", o mundo estreito e fragmentado, "um mundo presente por toda a parte em sua opaca multiplicidade", uma segunda natureza (idem, pp.62-3). De tal forma que neste quadro histórico "a mudança nunca poderá ser realizada pela arte: a grande épica é uma forma ligada à empiria do momento histórico" (idem, p.160). Ou seja, ele coloca o problema novamente em termos fichtianos ao sustentar que só na ação a harmonia poderia ser recuperada e, em termos hegelianos, ao pensar o tempo como o local da reconciliação dos indivíduos na história.

Para Guy Haarscher, a problemática da forma em $A$ teoria do romance remete ao sistema hegeliano, especificamente, à filosofia do jovem Hegel, para a qual a essência não é mais apenas o ideal subjetivo, mas é o "espírito que se manifesta ele mesmo progressivamente na dialética dos fenômenos culturais e sociais"; a forma que se manifesta por meio das "figuras do tempo". Contudo, Guy Haarscher vê nessa totalidade que se aspira, mas que nunca se encontra, nessa relação à totalidade que confere a cada elemento seu lugar, mas lhe nega substancialidade, nessa elevação de todo elemento da vida à sua significação, no procedimento de tornar tudo significativo, isto é, neste procedimento simbólico, o perigo de que "o universo cultural, a ordem simbólica, não remeta mais a um fundamento exterior, mas ganhe autonomia, independência, como um mundo das coisas" (Haarscher, 1974, p.307). Um mundo não-totalizado, uma lucidez que ilumina apenas a percepção da absoluta obscuridade, a ironia do romancista como lucidez máxima.

Ora, a preocupação não parece de todo procedente especialmente se sabemos dos desdobramentos futuros da obra lukácsiana: a totalidade que era pensada como numa relação ontológica entre o eu e o mundo, transforma-se em 1923, a partir de História e consciência de classe, em totalidade social e histórica.

De tal forma que, se a reflexão que o romance possibilita termina pela constatação quase perversa da vitória da ironia como forma inevitável da "profunda desesperança", estamos, sim, diante de uma perspectiva trágica, mas jamais niilista, pois o romance não se perdeu em um mundo de sonhos, ilusões e imaginação, nem sucumbiu à atração da coisa-em-si, da pura exterioridade, ao descrever ingenuamente o mundo empírico; ao contrário, exacerbou a insuficiência do mundo tornado opaco, denunciando sua inessencialidade, o que está ausente, sua pretensa auto-suficiência, sua "segunda natureza". O hiato entre sujeito e objeto não é abolido, mas exacerbado. É o máximo de lucidez possível, que transforma esse saber precário e insuficiente num valor moral: em um apelo no horizonte à transformação do mundo. Uma saída hegeliana com finalidade ética, a do romance pôr a totalidade do mundo e, assim, ser a educação do homem cindido na sociedade 
burguesa. Mas, contra uma visão mítica da reconciliação, a operação desmistificadora crítica e negativa de $A$ teoria do romance. A totalidade não se mostra suscetível de representação, mas ela é horizonte, uma situação limite que permite pensar a modernidade (Jameson, 1992, pp.48-50). Eis sua significação simbólica. E por que não realista, se entendermos por este termo o conteúdo de verdade do gênero romance?

O romance é um "ato simbólico" de expressão da cisão. Uma expressão da insuficiência, de estranhamento, diante da distância entre o eu e o mundo, na qual o desejo pode falar, um Eros certamente platônico, é bem verdade. Mas é o enunciador de um simbolismo consciente e não mágico. Uma reflexão imanente, desde que entendamos por ela uma tentativa de recuperar a relação com a experiência vivida, mesmo que negativamente; com o que caracteriza a essência, o ser desta experiência na história. É o que permite a Adorno ir além e falar em uma "transcendência estética" que reflete o desencantamento do mundo. Distante de uma épica positiva, fundada na possibilidade de configurar o real em sua objetividade, Adorno fala em um épico negativo que denuncia a "mentira da representação", e da supremacia do sujeito, que reconhece sua impotência e desamparo diante da supremacia do mundo das coisas. Em "Posição do narrador no romance contemporâneo", Adorno retoma as sugestões de Lukács sobre Dostoiévski - a possibilidade de uma épica futura - sugerindo a idéia de que se Dostoiévski é "avançado", ou seja, se ele abre uma brecha para o futuro,

se existe psicologia em suas obras, ela é uma psicologia do caráter inteligível, da essência, e não do ser empírico, dos homens que andam por aí. Não é apenas porque o positivo e o tangível, incluindo a facticidade da interioridade, foram confiscados pela informação e pela ciência que o romance foi forçado a romper com esses aspectos e a entregar-se à representação da essência e de sua antítese distorcida, mas também porque, quanto mais densa e cerradamente se fecha a superfície do processo social da vida, tanto mais hermeticamente esta encobre a essência como um véu. (Adorno, 2003, p.57)

Ora, se a distância trágica é o que a forma romance permite ver, e se ela continua ecoando por meio do ensaio, então o fato de $A$ teoria do romance tornar-se um clássico é no mínimo preocupante. Pois ou é um indício de que a cisão da modernidade, o descompasso entre interioridade e mundo, continua real e insuperável quase um século depois; ou, ao contrário, alerta o leitor sobre a suspeita de que a cisão foi uma forma histórica de estranhamento diante do início da modernidade, de tal forma que quando ela ressurge hoje diante da sociedade burguesa consolidada, torna-se acima de tudo um mito alimentado pelo "solo da cultura" e, especialmente, pela arte moderna e suas derivações. Mito que, ao insistir em afirmar a marginalidade e negatividade da cultura em relação a esta sociedade administrada, continua fazendo desta distância trágica não uma forma de acesso à realidade do presente visando 
sua possível transformação, mas tão somente um símbolo esvaziado, um eco do passado que perpetua a adesão ao "meramente existente."

SILVA, A. A. da. The emptied symbol: young György Lukács's Theory of the Romance. Trans/Form/Ação, (São Paulo), v.29(1), 2006, p.79-94.

- ABSTRACT: The present article investigates how G. Lukács's Theory of the romance (1916), a fragmented and of occasion text, became a classic of the reflection on modernity. For Lukács, the novel is the correspondent artistic form to the fracture between the subject and the world, lived by the contemporary man. Using the concept of "emptied symbol" this text apprehends how far the author, when reviewing the previous classifications on the genre of novel, perpetuates the romantic tradition or breaks it, elaborating original concepts for the understanding of modernity in literature.

- KEYWORDS: Lukács, novel, modernity, romantism, simbolisation.

\section{Referências bibliográficas}

ADORNO, Theodor. "Anotações sobre Kafka" in: Prismas. São Paulo: Ática, 1998. "Notas de Literatura". São Paulo: Duas Cidades/Editora 34, 2003.

BENJAMIN, Walter. Origem do Drama Barroco Alemão. São Paulo: Brasiliense, 1984. JAMESON, Fredric. Marxismo e Forma. São Paulo: Graal, 1971.

O Inconsciente Político. São Paulo: Ática, 1992.

HAARSCHER, Guy. "Approche des écrits de jeunesse de Lukács". In: L'Ame et les formes. Paris: Gallimard, 1974.

KANT. Crítica da faculdade do juízo. Rio de Janeiro: Forense Universitária, 1993.

LÖWY, Michel. Romantismo e messianismo. São Paulo: Perspectiva, 1990. 1979.

LUKÁCS, Georg. L'Ame et les Formes. Paris: Gallimard, 1974.

A teoria do romance. São Paulo: Editora 34, 2000.

Probleme des Realismus, III. Berlin: Luchterhand Verlag, 1965.

La signification presente du Réalisme critique. Paris: Gallimard,1960.

MACHADO, Carlos Eduardo J. As formas e a vida. São Paulo: Editora Unesp, 2004.

MUNCH, Marc-Mathieu. La 'Symbolique' de Friedrich Creuzer. Paris: Editions Ophrys, 1976.

NOVALIS. Pólen. São Paulo: Iluminuras,1988.

ROCHLITZ, R. Le jeune Lukács. Théorie de la forme et philosophie de l'histoire. Paris: Gallimard, 1983. 
SCHLEGEL. Conversa sobre a Poesia e outros fragmentos. São Paulo, Iluminuras, 1994.

SZONDI, Peter, Poésie et poétique de l'idéalisme allemand. Paris, Gallimard,1974.

TODOROV, Tzvetan. Théories du symbole. Paris, Seuil, 1977.

Artigo recebido em 08/05; aprovado para publicação em 12/05. 